\title{
Uji Efektivitas Ekstrak Akar Tanaman lauh Putiah (Ficus racemosa L.) Terhadap Bakteri Escherichia coli dan Shigella dysenteriae Penyebab Diare
}

\section{Effectiveness assay of Lauh Putiah Plants Roots Extract (Ficus racemosa L.) Against Escherichia coli and Shigella dysenteriae Causes Diarrhea}

\author{
Beladiena Citra Siregar ${ }^{1}$, Welly Darwis ${ }^{2}$, Mardhatillah Sariyanti ${ }^{3}$ \\ ${ }^{1}$ Program Studi Kedokteran Fakultas Kedokteran dan IImu Kesehatan, Universitas Bengkulu \\ ${ }^{2}$ Jurusan Biologi Fakultas MIPA Universitas Bengkulu \\ ${ }^{3}$ Departemen Biomedik Fakultas Kedokteran dan Ilmu Kesehatan Universitas Bengkulu \\ Beladiena Citra Siregar ${ }^{1}$, Welly Darwis ${ }^{2}$, Mardhatillah Sariyanti ${ }^{3}$ \\ ${ }^{1}$ Medical Study Program, Faculty of Medicine and Health Sciences, University of Bengkulu \\ ${ }^{2}$ Biology Department, Faculty of Mathematics and Natural Science, University of Bengkulu \\ ${ }^{3}$ Biomedical Department , Faculty of Medicine and Health Sciences, University of Bengkulu \\ Corresponding email: mardhatillahs@unib.ac.id
}

\begin{abstract}
ABSTRAK
Latar Belakang: Diare merupakan salah satu masalah kesehatan di dunia, terutama di negara berkembang. Mortalitas diare berkisar $17,5-21 \%$ dengan ekuivalent 1,5 juta orang setiap tahunnya. Escherichia coli dan Shigella Sp. merupakan patogen utama penyebab diare. Farmakoterapi antibiotik yang diberikan pada penderita diare dengan infeksi bakteri memiliki berbagai efek samping, sehingga diperlukan pemanfaatan tanaman obat sebagai salah satu alternatif untuk mengatasi masalah tersebut. Berdasarkan studi etnobotani, akar lauh putiah (Ficus racemosa L.) merupakan salah satu tanaman obat tradisional yang banyak digunakan oleh masyarakat Desa Pasar Pino, Kabupaten Bengkulu Selatan, dalam pengobatan diare. Kebiasaan dan pengetahuan tersebut telah dilakukan secara turun-temurun, namun belum dilatarbelakangi studi ilmiah.

Metode: Ekstraksi akar lauh putiah dilakukan dengan metode maserasi menggunakan pelarut etanol $96 \%$ dan dilarutkan dengan dimetil sulfoksida (DMSO). Hasil ekstraksi kemudian dilakukan uji minimal inhibitory concentration (MIC) dengan variasi konsentrasi ekstrak yang digunakan, yaitu $10 \%, 20 \%$, $30 \%, 40 \%, 50 \%, 60 \%, 70 \%, 80 \%, 90 \%$, dan 100\%, kemudian dilakukan pengujian efektivitas. Konsentrasi terendah yang efektif dalam menghambat pertumbuhan bakteri uji ditentukan berdasarakan daya hambat pada konsentrasi $70-80 \%$ dari konsentrasi yang memiliki daya hambat terbaik, sehingga diperoleh 5 variasi konsentrasi pada uji efektifitas, yaitu $45 \%, 52,5 \%, 60 \%, 67,5 \%$, dan $75 \%$. Uji MIC dan uji efektifitas menggunakan metode difusi kertas cakram dengan parameter yang digunakan adalah besarnya zona hambat yang terbentuk disekitar kertas cakram. Kontrol positif yang digunakan adalah larutan antibiotik siprofloksasin $50 \mu \mathrm{g} / \mathrm{ml}$, baik untuk bakteri Escherichia coli maupun Shigella dysenteriae.

Hasil: Hasil uji fitokimia menunjukkan bahwa ekstrak akar lauh putiah mengandung senyawa alkaloid, tannin, dan terpenoid. Pada uji MIC ekstrak akar lauh putiah terhadap bakteri E. coli dan $S$. dysentriae tidak didapatkan kategori penghambatan kuat, namun kategori daya hambat sedang (5-10 $\mathrm{mm}$ ) dihasilkan oleh konsentrasi $60 \%, 70 \%, 80 \%$, dan $100 \%$. Berdasarkan analisis statistik pengujian ANOVA, pengaruh ekstrak akar lauh putiah dalam menghambat bakteri $E$. coli dan $S$. dysentriae memiliki nilai $F_{\text {hitung }}>F_{\text {tabel }}$ dengan nilai $\alpha=0,05$, kemudian dilanjutkan dengan uji Duncan dan didapatkan konsentrasi $60 \%$ (AE3) dan konsentrasi 87,5\% (BE4) sebagai konsentrasi yang efektif dalam menghambat pertumbuhan bakteri E. coli S. dysenteriae.
\end{abstract}

Kesimpulan: Ekstrak akar tanaman lauh putiah (Ficus racemosa L.) memiliki daya hambat terhadap pertumbuhan bakteri Escherichia coli dan Shigella dysentriae.

Kata kunci: Escherichia coli, Shigella dysenteriae, Lauh putiah, Ficus racemosa Linn. 


\begin{abstract}
Background: Diarrhea is one of health problems in the world and developing countries. Diarrhea mortality range is $17.5-21 \%$ with an equivalent of 1.5 million people per year. Escherichia coli and Shigella sp. are the main pathogen bacteria that causes diarrhea. Ciprofloxacin is common antibiotic that used to treat diarrhea, but it has various side effects. The use of medicinal plants is an alternative to overcome this problem. Lauh putiah roots is one of the traditional medicinal plants that has many benefits, one of the benefits is to produce antibacterial compounds. Lauh putiah roots is used as a medicine for people in Pasar Pino village, it used to heal diarrhea by drinking boiled water from Lauh putiah roots. These habits have been passed down through generations, but it has not been proofed by scientific studies.

Methods: Extraction of Lauh putiah root was done by maceration method using ethanol $96 \%$ and dissolved with dimethyl sulfoxide (DMSO). The extraction results are then carried out a minimal inhibitory concentration (MIC) test with a variety of extract concentrations used, namely $10 \%, 20 \%$, $30 \%, 40 \%, 50 \%, 60 \%, 70 \%, 80 \%, 90 \%$, and $100 \%$, then testing the effectiveness. The lowest concentration which is effective in inhibiting the growth of test bacteria is determined based on inhibition at a concentration of $70-80 \%$ of the concentration that has the best inhibitory power, in order to obtain 5 variations of concentration in the effectiveness test, namely $45 \%, 52.5 \%, 60 \%, 67,5 \%$, and $75 \%$. MIC and effectiveness test using the paper diffusion method with the parameters used are the amount of inhibition zone formed around the disc paper. The positive control used was a $50 \mu \mathrm{g} / \mathrm{ml}$ ciprofloxacin antibiotic solution, both for Escherichia coli and Shigella dysenteriae.

Results: Phytochemical test showed that Lauh putiah root extract contains alkaloids, tannins, and terpenoids. In MIC test of Lauh putiah root extract against E. coli and S. dysentriae bacteria, there was no strong inhibition category, but moderate inhibition category $(5-10 \mathrm{~mm})$ was produced by concentrations of $60 \%, 70 \%, 80 \%$, and $100 \%$. Based on ANOVA statistical analysis, the effect of Lauh putiah root extract had Fcount>Ftable with a value of $\alpha=0.05$, then continued with the Duncan test and obtained concentration of $60 \%$ (AE3) and $87.5 \%$ (BE4) as effective concentration in inhibiting the growth of $E$. coli and $S$. dysenteriae.

Conclusion: Lauh putiah Root Extract (Ficus racemosa L.) has inhibitory effect on the growth of Escherichia coli and Shigella dysentriae.
\end{abstract}

Keywords: Escherichia coli, Shigella dysenteriae, Lauh putiah, Ficus racemosa Linn.

\title{
PENDAHULUAN
}

Diare merupakan salah satu masalah kesehatan di dunia dan negara berkembang. Morbiditas dan mortalitas diare masih tinggi di negara berkembang ${ }^{1}$. Data Profil kesehatan Indonesia tahun 2016 oleh Kementerian Kesehatan kasus diare di Indonesia mencapai 6.897.453 kasus. Menurut data profil kesehatan Provinsi Bengkulu tahun 2017 kasus diare termasuk dalam golongan 10 penyakit terbanyak dan terus meningkat setiap tahunnya. Jumlah kasus diare di Provinsi Bengkulu pada tahun 2017 sebanyak 53.348 kasus diare dengan jumlah kasus tertinggi di kota Bengkulu yaitu 9.894 kasus dan terendah di Kabupaten Lebong sebanyak 3.077 kasus $^{2}$.

Tingginya kasus diare dapat dipengaruhi oleh beberapa faktor yaitu faktor infeksi (virus, bakteri, parasit), malabsorbsi makanan, status gizi balita, perilaku hygiene, dan kebersihan lingkungan ${ }^{3}$. Bakteri yang paling sering menyebabkan diare adalah Escherichia coli dan Shigella sp. dengan persentase masing-masing $20-30 \%$ dan $27,3 \%{ }^{4}$. Hal ini disebabkan penularan bakteri tersebut sangat mudah baik melalui air yang terkontaminasi, makanan, dan feses ${ }^{5}$. 
Penatalaksanaan dalam kasus diare diperlukan farmakoterapi yang cepat dan tepat. Terapi yang diberikan pada kasus diare dengan infeksi bakteri berupa antibiotik, seperti golongan flurokuinolon, azitromisin, seftriakson, dan rifampisin ${ }^{6}$. Penggunaan antibiotik untuk pengobatan diare perlu diperhatikan karena antibiotik mempunyai efek toksik dan berbahaya apabila masuk ke dalam tubuh dalam dosis tinggi ${ }^{7}$. Efek antibiotik dapat memengaruhi bagian-bagian tubuh tertentu dan dapat mengakibatkan timbulnya efek samping, seperti mual, insomnia, nyeri kepala, pusing, gangguan gastrointestinal, gangguan fungsi hati, ruam kulit, dan superinfeksi ${ }^{5}$. Penggunaan antibiotik dalam jangka waktu yang lama dan penggunaan yang tidak terkontrol dengan baik dapat menyebabkan terjadinya resistensi antibiotik yang menyebabkan penurunan kemampuan antibiotik tersebut dalam mengobati infeksi dan penyakit ${ }^{8}$. Oleh karena itu, diperlukan alternatif lain untuk mengobati diare agar terhindar dari efek samping, dan mencegah resistensi antibiotik, yaitu dengan memanfaatkan tanaman obat.

Pengobatan tradisional masih banyak digunakan oleh masyarakat Indonesia mengingat efek samping yang minimum dalam mengobati penyakit. Berdasarkan survey lapangan oleh peneliti di Desa Pasar Pino, Kecamatan Pino Raya, Kabupaten Bengkulu Selatan, Provinsi Bengkulu terdapat salah satu tanaman obat yang digunakan oleh masyarakat, yaitu akar lauh putiah (Ficus racemosa L.) sebagai obat herbal tradisional dalam pengobatan diare. Penggunaan akar pada masyarakat Desa Pasar Pino dengan cara meminum air rebusan dari akar lauh putiah. Kebiasaan dan pengetahuan tersebut telah secara turun-temurun, namun belum dilatarbelakangi studi ilmiah, sehingga peneliti tertarik untuk mendapatkan data ilmiah mengenai ekstrak akar tanaman lauh putiah.

Ekstrak akar lauh putiah mengandung senyawa aktif yang berfungsi sebagai antibakteri ${ }^{9}$. Kandungan kimia yang terdapat pada akar lauh putiah adalah tanin, flavonoid, sterol, alkaloid, dan saponin $^{10}$. Selain itu, kandungan flavonoid yang terdapat pada akar lauh putiah dapat berfungsi sebagai antioksidan, yaitu sebagai akseptor yang baik terhadap radikal bebas ${ }^{11}$. Kandungan tanin yang dimiliki oleh akar lauh putiah juga dapat mengganggu permeabilitas dinding sel atau membrane sel bakteri. Akibat terganggunya permeabilitas, sel tidak dapat melakukan aktivitas hidup sehingga pertumbuhannya terhambat atau bahkan mati ${ }^{12}$. Senyawa alkaloid yang dimiliki akar lauh putiah memiliki fungsi sebagai antibakteri ${ }^{13}$. Beberapa kandungan senyawa yang terdapat dalam akar lauh putiah dapat dimanfaatkan sebagai obat diare. 
Dalam penelitian ini selain untuk mengetahui kandungan yang terdapat dalam akar lauh putiah juga untuk memanfaatkan sumber daya alam yang tersedia, serta dapat memberikan informasi kepada masyarakat mengenai ekstrak akar lauh putiah dalam menghambat pertumbuhan bakteri E.coli dan S. dysenteriae yang digunakan untuk pengobatan diare pada masyarakat Desa Pasar Pino, Kecamatan Pino Raya Bengkulu Selatan Provinsi Bengkulu, maka akan dilakukan penelitian tentang ekstrak akar lauh putiah terhadap bakteri E. coli dan S. dysenteriae penyebab diare.

\section{METODE}

Jenis penelitian ini adalah studi analitik eksperimental laboratorium, dilakukan pengujian aktivitas antibakteri dengan berbagai variasi konsentrasi ekstrak akar lauh putiah menggunakan uji difusi cakram. Indikator metode ini adalah adanya zona hambat yang terbentuk di sekitar kertas cakram yang sudah diteteskan dengan ekstrak akar lauh putiah, selanjutnya diukur berapa besar diameter zona hambat terhadap bakteri E. coli dan S. dysenteriae. Semakin besar efektivitas daya hambat pertumbuhan bakteri, maka zona hambat yang terbentuk akan semakin luas.

Akar lauh putiah diperoleh dari Desa Pasar Pino, Kecamatan Pino Raya Kabupaten Bengkulu Selatan Provinsi Bengkulu diambil sebanyak 4 kg dibersihkan dari kotoran-kotoran, lalu dicuci dengan air yang mengalir hingga bersih lalu dipotong-potong atau dirajang halus dan dikeringkan sampai beratnya konstan. Sediaan ekstrak etanol dibuat dengan cara maserasi, yaitu dengan memasukkan akar lauh putiah yang telah berbentuk potongan kecil ke dalam Erlenmeyer $2000 \mathrm{ml}$ kemudian ditambahkan etanol 96\% dan maserasi selama 5 hari. Filtrat yang telah diperoleh dipekatkan menggunakan rotary evaporator bertujuan untuk menguapkan pelarut etanol $96 \%$ sehingga diperoleh ekstrak cair akar lauh putiah tanpa pelarut. Untuk mendapatakan ekstrak kental maka ekstrak cair diuapkan pada penangas air (water bath) dengan suhu $40^{\circ} \mathrm{C}-50^{\circ} \mathrm{C}$ hingga diperoleh ekstrak kental dan ditimbang ${ }^{14}$. Hasil ekstraksi kemudian dilakukan uji fitokimia berupa uji flavonoid, uji terpenoid, uji alkaloid, uji tannin, dan uji saponin. Selanjutnya dilakukan uji Minimal Inhibitory Concentration (MIC) dengan variasi konsentrasi ekstrak yang digunakan, yaitu 10\%, 20\%, 30\%, 40\%, $50 \%, 60 \%, 70 \%, 80 \%, 90 \%$, dan 100\%, kemudian dilakukan pengujian efektivitas. Konsentrasi terendah yang efektif dalam menghambat pertumbuhan bakteri uji ditentukan berdasarakan daya hambat pada konsentrasi $70-80 \%$ dari konsentrasi yang memiliki daya hambat terbaik, sehingga diperoleh 5 variasi konsentrasi pada uji efektifitas, yaitu $45 \%, 52,5 \%, 60 \%, 67,5 \%$, dan $75 \%$. 
Pengujian MIC dan efektivitas tersebut menggunakan metode difusi agar dan parameter yang digunakan ialah besarnya zona hambat yang terbentuk disekitar kertas cakram, dan kontrol positif yang digunakan adalah larutan antibiotik siprofloksasin $50 \mu \mathrm{g} / \mathrm{ml}$ untuk bakteri $E$. coli dan bakteri $S$. dysenteriae. Variabel bebas pada penelitian ini adalah berbagai variasi konsentrasi ekstrak akar lauh putiah terhadap inokulasi bakteri E. coli dan S. dysenteriae. Variabel terikat pada penelitian ini adalah zona hambat yang terbentuk di sekitar cakram terhadap variasi konsentrasi ekstrak akar lauh putiah.

Data yang didapat akan diolah menggunakan program Stastictical Program Service Solution (SPSS) untuk mengetahui zona hambat yang bermakna dari variasi konsentrasi Akar Tanaman lauh putiah (Ficus racemosa L.). Uji yang digunakan adalah One Way ANOVA dengan syarat distribusi data harus normal dan varians data harus sama. Jika pada hasil uji One Way ANOVA di dapatkan $p<0,05$, maka akan dilanjutkan uji Duncan sebagai uji lanjut (post hoc test) untuk mengetahui perbedaan daya hambat pada tiap perlakuan ${ }^{15}$.

\section{HASIL}

Pembuatan ekstrak akar lauh putiah didapatkan melalui beberapa proses yang telah dilakukan. Proses pembuatan ekstrak diawali dengan pembuatan simplisia dengan bahan utama akar lauh putiah sebanyak $4 \mathrm{~kg}$ yang diperoleh dari satu pohon Lauh putiah di Desa Pasar Pino, Kecamatan Pino Raya Kabupaten Bengkulu Selatan Provinsi Bengkulu. Akar yang dipilih adalah akar segar dengan konsistensi keras, berwarna coklat tua yang terdapat di dalam tanah dengan kondisi baik. Pencucian akar lauh putiah menggunakan air mengalir, selanjutnya di potong kecil-kecil dan dikering anginkan dengan suhu kamar $25^{\circ} \mathrm{C}-35^{\circ} \mathrm{C}$ selama 5 hari untuk mengurangi kadar air, sehingga didapatkan berat kering sebanyak $1,5 \mathrm{~kg}$ dan setelah dihaluskan menggunakan blender didapatkan berat simplisia kering sebanyak 800 gr. Hasil ekstraksi dengan metode maserasi diperoleh filtrat akar lauh putiah berwarna hijau jernih sebanyak 3,38 liter dan setelah diuapkan menggunakan rotary evaporator didapatkan ekstrak cair berwarna hijau tua. Hasil pemanasan ekstrak cair dengan waterbath dan oven diperoleh ekstrak kental berwarna hijau tua pekat menyerupai pasta sebanyak $10,5 \mathrm{gr}$ 
A. Uji Fitokimia Akar lauh putiah

Berdasarkan uji fitokimia, ekstrak akar lauh putiah mengandung senyawa alkaloid, tannin dan terpenoid pada (Tabel 1.)

Tabel 1. Hasil Pengujian Fitokimia

\begin{tabular}{ccc}
\hline No & Uji Fitokimia & Akar lauh putiah \\
\hline 1 & Alkaloid & + \\
2 & Flavonoid & - \\
3 & Saponin & - \\
4 & Tanin & + \\
5 & Terphenoid & + \\
\hline
\end{tabular}

B. Uji Efektivitas Ekstrak Akar lauh putiah Terhadap Escherichia coli

Hasil uji efektivitas ekstrak akar lauh putiah terhadap bakteri E. coli pada (Tabel 2. )

Tabel 2. Rata-rata Diameter Daya Hambat Ekstrak Akar lauh putiah Terhadap Pertumbuhan Bakteri Escherichia coli

\begin{tabular}{cccc}
\hline Perlakuan (Kode) & $\begin{array}{c}\text { Rerata } \\
\text { Daya Hambat }(\mathbf{m m})\end{array}$ & $\begin{array}{c}\text { Standar Deviasi } \\
(\mathbf{m m})\end{array}$ & $\begin{array}{c}\text { Kategori } \\
\text { Daya Hambat }\end{array}$ \\
\hline$(\mathrm{K}-)$ & 0 & 0 & $\begin{array}{c}\text { Tidak ada daya } \\
\text { hambat }\end{array}$ \\
$45 \%(\mathrm{AE} 1)$ & 2,28 & $\pm 0,51$ & Lemah \\
$52,5 \%(\mathrm{AE} 2)$ & 2,47 & $\pm 0,43$ & Lemah \\
$60 \%(\mathrm{AE} 3)$ & 2,76 & $\pm 0,76$ & Lemah \\
$67,5 \%(\mathrm{AE} 4)$ & 2,66 & $\pm 0,47$ & Lemah \\
$75 \%(\mathrm{AE} 5)$ & 2,40 & $\pm 0,73$ & Lemah \\
$(\mathrm{K}+)$ & 13,00 & 0 & Kuat \\
\hline
\end{tabular}

Berdasarkan (Tabel 2) rata-rata zona hambat yang dihasilkan oleh ekstrak akar lauh putiah terhadap pertumbuhan bakteri E. coli termasuk ke dalam kategori daya hambat lemah ${ }^{16}$. Hasil yang diperoleh dari uji efektivitas antibakteri tersebut selanjutnya dianalisa menggunakan SPSS 25.0 dengan uji statistik Anova (One-Way Analysis of Variance). Hasil analisis uji statistik tersebut menunjukkan nilai yang signifikan, sehingga dapat diketahui bahwa pemberian ekstrak akar lauh putiah terdapat perbedaan yang nyata terhadap pertumbuhan bakteri Shigella dysenteriae. Berdasarkan uji Anova didapatkan nilai Fhitung yaitu 276,508, hal ini menyatakan bahwa Fhitung lebih besar daripada Ftabel yaitu 2,77 pada taraf $0,05 \%$ dan 4,25 pada taraf $0,01 \%$. Uji lanjutan yang digunakan yaitu uji Duncan pada (Tabel 3). 
Tabel 3. Hasil uji Duncan Zona Hambat Ekstrak Akar lauh putiah terhadap Pertumbuhan Bakteri E.coli

\begin{tabular}{|c|c|c|c|c|c|c|c|c|c|c|}
\hline \multirow[t]{3}{*}{ Perlakuan } & \multirow{3}{*}{$\begin{array}{c}\text { Rerata } \\
\text { Zona } \\
\text { Hambat }\end{array}$} & \multicolumn{9}{|c|}{ Selisih Antar Perlakuan } \\
\hline & & $\mathrm{K}(-)$ & $45 \%$ & $75 \%$ & $52,5 \%$ & $67,5 \%$ & $60 \%$ & $\mathrm{~K}(+)$ & LSR & Notasi $^{*}$ \\
\hline & & 0,00 & 2,28 & 2,40 & 2,47 & 2,66 & 2,76 & & $1 \%$ & \\
\hline $\mathrm{K}(-)$ & 0,00 & 0,00 & & & & & & & 0,88 & a \\
\hline $45 \%(A E 1)$ & 2,28 & $2,28^{*}$ & 0,00 & & & & & & & $b$ \\
\hline 75\% (AE2) & 2,40 & $2,40^{*}$ & 0,12 & 00,0 & & & & & & b \\
\hline $52,5 \%(A E 3)$ & 2,47 & $2,47^{*}$ & 0,19 & 0,07 & 0,00 & & & & & b \\
\hline $67,5 \%(A E 4)$ & 2,66 & $2,66^{*}$ & 0,38 & 0,26 & 0,19 & 0,00 & & & & b \\
\hline $60 \%(A E 5)$ & 2,76 & $2,76^{*}$ & 0,48 & 0,29 & 0,29 & 0,10 & 0,00 & & & $\mathrm{~b}$ \\
\hline $\mathrm{K}(+)$ & 13,00 & $13,00^{*}$ & $10,72^{*}$ & $10,60^{*}$ & $10,53^{*}$ & $10,34^{*}$ & $10,24^{*}$ & 0,00 & & c \\
\hline
\end{tabular}

Keterangan : ${ }^{*}=$ angka-angka yang diikuti oleh notasi yang sama berarti tidak berbeda nyata, dan apabila tidak disertai huruf yang sama maka berbeda nyata

Berdasarkan hasil uji Duncan (Tabel 3) didapatkan LSR dengan nilai 0,88 dengan selisih antar perlakuan pada (Tabel 3). Keseluruhan konsentrasi ekstrak akar lauh putiah efektif dalam menghambat pertumbuhan bakteri E. coli, akan tetapi untuk mendapatkan hasil yang lebih efektif sebaiknya menggunakan konsentrasi $60 \%$ karena memiliki daya hambat yang paling baik dengan konsentrasi terendah diantara seluruh konsentrasi yang di uji

C. Uji Efektivitas Ekstrak Akar lauh putiah Terhadap Shigella dysentriae

Hasil uji efektivitas ekstrak akar lauh putiah terhadap bakteri Shigella dysenteriae pada (Tabel 4).

Tabel 4. Rata-rata Diameter Daya Hambat Ekstrak Akar lauh putiah Terhadap Pertumbuhan Bakteri Shigella dysenteriae

\begin{tabular}{cccc}
\hline Perlakuan (Kode) & $\begin{array}{c}\text { Rata-rata } \\
\text { Daya Hambat }(\mathbf{m m})\end{array}$ & $\begin{array}{c}\text { Standar Deviasi } \\
(\mathbf{m m})\end{array}$ & Kategori Daya Hambat $^{\star}$ \\
\hline K (-) & 0 & 0 & Tidak ada daya hambat \\
$65 \%$ (BE1) & 5,00 & $\pm 0,32$ & Lemah \\
$72,5 \%$ (BE2) & 4,83 & $\pm 1,1$ & Lemah \\
$80 \%$ (BE3) & 8,03 & $\pm 1,2$ & Sedang \\
$87,5 \%$ (BE4) & 11,51 & $\pm 2,75$ & Kuat \\
$95 \%$ (BE5) & 9,27 & $\pm 1,85$ & Sedang \\
K (+) & 39,00 & 0 & Kuat \\
\hline
\end{tabular}

Pada (Tabel 4) didapatkan rata-rata zona hambat yang dihasilkan oleh ekstrak akar lauh putiah terhadap pertumbuhan bakteri Shigella dysenteriae termasuk ke dalam kategori daya hambat lemah, sedang dan kuat ${ }^{16}$. Hasil yang diperoleh dari uji efektivitas antibakteri tersebut selanjutnya dianalisa menggunakan SPSS 25.0 dengan uji statistik Anova (One-Way Analysis of Variance). Hasil analisis uji statistik tersebut menunjukkan nilai yang signifikan, sehingga dapat diketahui bahwa pemberian ekstrak akar lauh putiah terdapat perbedaan yang nyata terhadap pertumbuhan bakteri 
Shigella dysenteriae. Berdasarkan Uji Anova didapatkan nilai $F$ hitung yaitu 58,268 , hal ini menyatakan bahwa $F$ hitung lebih besar daripada $F$ tabel yaitu 2,77 pada taraf $0,05 \%$ dan 4,25 pada taraf $0,01 \%$. Uji lanjutan yang digunakan setelah uji tersebut yaitu uji Duncan pada (Tabel 5).

Tabel 5. Hasil uji Duncan Zona Hambat Ekstrak Akar lauh putiah terhadap Pertumbuhan Bakteri S. dysentriae

\begin{tabular}{|c|c|c|c|c|c|c|c|c|c|c|}
\hline \multirow[b]{2}{*}{ Perlakuan } & \multirow{2}{*}{$\begin{array}{c}\text { Rerata } \\
\text { Zona } \\
\text { Hambat }\end{array}$} & \multicolumn{9}{|c|}{ Selisih Antar Perlakuan } \\
\hline & & $\begin{array}{l}\mathrm{K}(-) \\
0,00\end{array}$ & $\begin{array}{c}72,5 \% \\
4,83\end{array}$ & $\begin{array}{l}65 \% \\
5,00\end{array}$ & $\begin{array}{l}80 \% \\
8,03\end{array}$ & $\begin{array}{l}95 \% \\
9,27\end{array}$ & $\begin{array}{c}87,5 \% \\
11,51\end{array}$ & $\mathrm{~K}(+)$ & $\begin{array}{l}\text { LSR } \\
1 \%\end{array}$ & Notasi $^{*}$ \\
\hline $\mathrm{K}(-)$ & 0,00 & 0,00 & & & & & & & 0,153 & $a$ \\
\hline $\begin{array}{c}72,5 \% \\
\text { (BE2) }\end{array}$ & 4,83 & $4,83^{*}$ & 0,00 & & & & & & & b \\
\hline $\begin{array}{l}65 \% \\
\text { (BE1) }\end{array}$ & 5,00 & $5,00^{*}$ & $0,17^{*}$ & 0,00 & & & & & & c \\
\hline $\begin{array}{c}80 \% \\
\text { (BE3) }\end{array}$ & 8,03 & $8,03^{*}$ & $3,20^{*}$ & $3,03^{*}$ & 0,00 & & & & & $d$ \\
\hline $\begin{array}{c}95 \% \\
\text { (BE5) }\end{array}$ & 9,27 & $9,27^{*}$ & $4,42^{*}$ & $4,27^{\star}$ & $1,24^{*}$ & 0,00 & & & & e \\
\hline $\begin{array}{l}87,5 \% \\
\text { (BE4) }\end{array}$ & 11,51 & $11,51^{*}$ & $6,68^{*}$ & $6,51^{*}$ & $3,48^{*}$ & $2,24^{*}$ & 0,00 & & & $f$ \\
\hline $\mathrm{K}(+)$ & 39,00 & $39,00^{*}$ & $34,17^{*}$ & $34,00^{*}$ & $30,97^{*}$ & $29,73^{*}$ & $27,49^{*}$ & 0,00 & & $g$ \\
\hline
\end{tabular}

Keterangan : ${ }^{*}$ = angka-angka yang diikuti oleh notasi yang berbeda berarti berbeda nyata

Berdasarkan hasil uji Duncan didapatkan LSR dengan nilai 0,153 dengan selisih antar perlakuan pada (Tabel 5). Keseluruhan konsentrasi ekstrak akar lauh putiah efektif dalam menghambat pertumbuhan bakteri S.dysentriae, akan tetapi untuk mendapatkan hasil yang lebih efektif sebaiknya menggunakan konsentrasi $87,5 \%$ karena memiliki daya hambat yang paling baik dengan konsentrasi terendah diantara seluruh konsentrasi yang diuji

\section{PEMBAHASAN}

Berdasarkan uji uji fitokimia didapatkan hasil kualitatif kandungan senyawa metabolit sekunder pada akar lauh putiah, yaitu tannin, alkaloid, dan terpenoid. Menurut Devans (2017) metabolit sekunder yang terdapat pada akar lauh putiah (Ficus racemosa L.) yaitu tanin, flavonoid, sterol, alkaloid, saponin, terpenoid, betasitosterol, phenol, quinins, glikosida, glukopiranosida ${ }^{10}$. Hasil negatif pada uji flavonoid dan saponin dapat dipengaruhi oleh pelarut yang digunakan pada tahap ekstraksi serta faktor lingkungan, seperti suhu, intensitas cahaya, dan letak geografis ${ }^{17}$.

Uji MIC dan uji efektifitas menunjukkan adanya kemampuan daya hambat pada semua konsentrasi ekstrak akar lauh putiah terhadap pertumbuhan bakteri Escherichia coli dan Shigella dysentriae, namun peningkatan zona hambat tidak berbanding lurus dengan peningkatan konsentrasi 
ekstrak. Beberapa faktor yang dapat memengaruhi hasil tersebut adalah kurang homogennya ekstrak dan pelarut (DMSO) pada saat pengenceran, perbedaan kecepatan difusi senyawa antibakteri pada media agar, serta jenis dan konsentrasi senyawa antibakteri ${ }^{18,19}$. Hasil uji fitokimia yang diperoleh tidak menunjukkan jumlah senyawa metabolit sekunder secara kuantitatif, sehingga tidak diketahui konsentrasi senyawa tersebut yang terkandung dalam ekstrak akar lauh putiah.

Hasil uji efektivitas ekstrak akar lauh putiah terhadap bakteri E.coli yang telah dilakukan peneliti sejalan dengan penelitian yang dilakukan oleh Mathur $(2011)^{20}$ pada uji ekstrak akar lauh putiah pada bakteri E.coli didapatkan zona hambat lemah. Hal ini dapat terjadi karena bakteri E. coli merupakan bakteri Gram negatif dengan dinding sel yang dilapisi oleh lipopolisakarida yang lebih tebal dibandingkan dengan bakteri Gram negatif lainnya yang terdiri dari lipid A, inti lipopolisakarida dan rantai O. Lipopolisakarida pada bakteri E. coli ini tersusun atas berbagai gula seperti galaktosa, glukosa, hepatosa, N-Asetilglukosamin, glukosamin ${ }^{21}$. Selain itu, hasil negatif pada uji fitokimia senyawa metabolit sekunder flavonoid dan saponin juga dapat memengaruhi hasil pengujian daya hambat karena kedua senyawa tersebut juga berperan sebagai antibakteri melalui mekanisme pembentukan senyawa kompleks terhadap protein ektraseluler yang dapat mengganggu integritas membran sel bakteri ${ }^{22}$.

Dari hasil penelitian didapatkan bahwa ekstrak akar lauh putiah lebih efektif dalam menghambat pertumbuhan bakteri $S$. dysentriae dibandingkan bakteri E. coli. Hal ini disebabkan karena S. dysentriae memiliki lapisan peptidoglikan lebih tipis yang menyusun dinding sel dibandingkan dengan bakteri Gram negatif yang lain, sehingga mudah dihambat pada konsentrasi yang rendah, semakin tipis lapisan peptidoglikan yang menyusun dinding sel bakteri maka bakteri tersebut semakin sensitif terhadap antibakteri ${ }^{19}$. Pada bakteri Gram negatif, dinding selnya mengandung tiga komponen yang terletak dibagian luar dari lapisan peptidoglikan, yaitu lipoprotein, membran luar, dan lipopolisakarida. Membran luar dari bakteri Gram negatif mampu mencegah molekul hidrofobik masuk dan berperan dalam melindungi sel bakteri dari substansi yang merusak. Membran luar juga mempunyai kanal-kanal khusus yang terdiri atas molekul protein yang disebut porin. Porin memungkinkan terjadinya proses difusi pasif dari komponen hidrofilik dengan berat molekul rendah,sedangkan molekul yang lebih besar relatif lebih lambat untuk menembus membran luar. Antibiotik merupakan molekul besar, sehingga akan relatif lambat untuk menembus membran luar, dalam penelitian ini antibiotik yang dimaksud adalah ekstrak akar lauh putiah. Porin inilah yang 
kemungkinan menyebabkan ekstrak akar lauh putiah lebih sulit menembus atau masuk ke dalam sel bakteri, sehingga menyebabkan zona hambat yang terbentuk pada bakteri E. coli kecil atau tidak ada yang menunjukkan kategori zona hambat yang kuat ${ }^{23}$.

Adapun keterbatasan yang ditemukan pada penelitian ini perlakuan kontrol positif dan kontrol negatif tidak dilakukan dalam satu cawan petri yang sama dengan perlakuan berbagai variasi ekstrak akar lauh putiah terhadap inokulasi bakteri, selanjutnya pada penelitian ini tidak dilakukan blind pada saat perhitungan pengukuran zona hambat yang terbentuk dari ekstrak akar lauh putiah, serta perhitungan dan metode pembuatan larutan siprofloksasin yang digunakan pada penelitian kurang tepat karena lansung membuat larutan dari hasil pengukuran siprofloksasin yang dibutuhkan.

\section{KESIMPULAN DAN SARAN}

Berdasarkan hasil penelitian didapatkan adanya efektivitas antibakteri ekstrak akar lauh putiah (Ficus racemosa L.) terhadap bakteri E. coli dan S. Dysentriae dengan konsentrasi efektif untuk masing-masing bakteri adalah $60 \%$ (AE3) dan $87,5 \%$ (BE4). Penulis menyarankan sebaiknya perlu dilakukan pengujian lanjut secara in vivo untuk mengetahui efek pada hewan coba dan uji klinik sebelum digunakan sebagai alternatif pengobatan di masyarakat. Selain itu, perlu dilakukan uji fitokimia secara kuantitatif untuk mengetahui kadar metabolit sekunder pada ekstrak akar lauh putiah serta dilakukan penelitian lanjutan sesuai dengan kebiasaan masyarakat Desa Pasar Pino berupa air rebusan akar lauh putiah.

\section{DAFTAR PUSTAKA}

1. Kementerian Kesehatan RI. 2011.Situasi diare di Indonesia. Buletin jendela data \& informasi kesehatan, 2, pp. 1-44.

2. Dinkes Provinsi Bengkulu. 2017. Profil Kesehatan Provinsi Bengkulu Tahun 2017, pp. 1-154 : Dinas Kesehatan Provinsi Bengkulu.

3. Ngastiyah. 2005. Perawatan anak sakit. Penerbit Buku Kedokteran EGC:Jakarta.

4. World Health Organization. 2005. The treatment of diarrhoea, a manual for physicians and other senior health workers, pp. 1-50. doi: ISBN 9241593180.

5. Jawetz, E Melnick, E.A. dan Adelberg's, 2013. Mikrobiologi kedokteran. Jakarta; Salemba Medika

6. Amin, L. Z. 2015. Tatalaksana Diare Akut, Cdk-230, 42(7), pp. 504-508

7. Njume C., Afolayan A.J., Samie A., Ndip R.N. 2011. Inhibitory and bactericidal potential of crude acetone extracts of Combretum molle (Combretaceae) against drug-resistant strains of Helicobacter pylori. J. Health Popul. Nutr;29:438-445

8. Werner, N. L Michelle T Hecker, Ajay K Sethiand Curtis J Donskey. 2011. Unnecessary use of fluoroquinolone antibiotics in hospitalized patients. BMC Infectious Diseases. Biomed Central Ltd, 11(1), p. 187. doi: 10.1186/1471-2334-11-187. 
9. Murti, K. and Kumar, U. 2011. Antimicrobial activity of ficus benghalensis and ficus racemosa roots L., Am. J.microbiol, 2(1), pp. 21-24.

10. Devans. 2017. Phytochemical Ficus racemosa Linn.: a comprehensive review, 3(4), pp. 14231431.

11. Sudarmanto, dan Tati Suhartati. 2015. Aktivitas antioksidan senyawa flavonoid pada kulit akar tanaman ara (Ficus racemosa, L), Skripsi. pp. 137-141: Fakultas MIPA Universitas Lampung.

12. Ajizah, A .2004. Sensitivitas Salmonella typhimurium terhadap ekstrak daun Psidium guajava L. Bioscientiae. 1(1) : 31-8.

13. Robinson, T.1995. Kandungan organik tumbuhan tinggi. Penerbit ITB: Bandung. Hal 71, 153-156, 191 dan 281.

14. Moerfiah dan F.D.S., Supomo. 2011. Pengaruh ekstrak daun sirih merah ( Piper cf. fragile Benth.) terhadap bakteri penyebab sakit gigi. J.Ekologia. Vol. 11 No.1

15. Dahlan S., 2009. Statistik untuk kedokteran dan kesehatan. Jakarta: Salemba Medika

16. Davis, W.W. dan T.R., Stout. 1971. Disc plate methods of microbiological antibiotic assay. microbiology pp: 22: 659-665

17. Pingale Tanvil.2019. Antibacterial and antifungal approaches of Ficus racemosa. Pharmacogn J. 2019; 11(2): 355-357.

18. Mathur Abhishek. 2011. Phytochemical investigation and in vitro antimicrobial activity of different parts of Ficus racemosa L. 2 (2): 270-275.

19. Brooks GF .2007. Mikrobiologi kedokteran jawetz, melnick, \& adelberg. Edisi 23. Jakarta: EGC, pp: 258-60, 170-171

20. Iriano, A. 2008. Efek antibakteri infusum aloe vera terhadap porphyromonas gingivalis in vitro (perbandingan metode ekstraksi maserasi dan infundasi). Skripsi. Fakultas Kedokteran Gigi Program Studi Pendidikan Dokter Gigi. Jakarta: Universitas Indonesia.

21. Hossan,Sayeed. 2014. In-vitro antimicrobial activity of methanolic extract of Ficus racemosa Linn. fruits and roots .J.Sci.res.pp: 12-16

22. Prescott, L.M., 2002, Prescott-Harley-Klein's: Microbiology, 5th ed., 553, The McGraw-Hill Companies, New York.Robinson, T.1995. Kandungan organik tumbuhan tinggi. Penerbit ITB : Bandung. hal 71, 153-156, 191 dan 281. 